\title{
Generic Structure Potential of Christian Apologetics
}

\author{
Onwu Inya (Ibadan, Nigeria)
}

\begin{abstract}
Religious texts have been examined by scholars from different theoretical standpoints. However, a close survey of the literature reveals that little attention has been paid to Christian apologetics from a linguistic perspective. Also, an examination of studies along the lines of Generic Structure Potential (henceforth GSP) shows that the genre status of Christian apologetics has not been indicated. This gap provides the motivation for this paper, which investigates the GSP of Christian apologetics. Twenty texts written by various key contemporary apologetic writers were purposively selected for the study. The following generic structure potential catalogue was generated:
\end{abstract}

\section{$\left[T T^{\wedge} A N\right]^{\wedge}[B I]^{\wedge} P C P . \wedge A O P . \wedge A . \wedge E L . \wedge(T M s)^{\wedge}[F]$}

The paper reveals that the elements of the GSP concertedly work to advance, argue for or defend the Christian belief system. The paper also suggests that the model could be applied to other forms of apologetic instances.

\section{Introduction}

Arguably, religious text is one of the most influential texts in contemporary society. It manifests in scriptures, sermons, Bible study outlines and theological writings and apologetic treatises. Scholars have investigated these manifestations of religious texts from different theoretical standpoints. For instance, Crystal (1965), and Crystal and Davy (1969) consider the language of religion from a linguistic stylistic perspective; Samarin (1976), using Speaking grid, examines the sociolinguistic features of a typical religious community; Babatunde (1986) does a speech act analysis of evangelical Christian sermons in Nigeria; Odebunmi (2007b) makes a stylistic analysis of electronic advertisements; and Taiwo (2004) looks at tenor in electronic media discourse in Nigeria. A close survey of the literature, available to us, reveals that little attention has been paid to Christian apologetics from a discourse analytic point of view, using the Generic Structure Potential model developed by Halliday and Hasan (1985), which helps to establish the genre status of a discourse. This paper, therefore, aims to examine the Generic Structure Potential of Christian apologetics to establish its genre status.

\section{Christian Apologetics: Meaning and Goals}

"Apologetics" is described as the defence of the Christian faith (Boa/Bowman 2005). The word is derived from the Greek word apologia, which was originally used to refer to a speech made in defence of oneself or an answer given in reply to an accusation. In ancient Athens, it referred to a defence made in the courtroom as part of the normal judicial procedure. After the accusation, the defendant would be allowed to refute charges with a defence or reply (apologia). The accused person would then attempt to "speak away" (apo-away, logia- 
speech) the accusation (Batts 1977). The classic example of such an apologia was Socrates' defence against the charge of preaching strange gods, a defence reported by his most famous pupil, Plato, in a dialogue called The Apology.

In the literature, apologetics has at least three functions or goals. Beattie (1903: 56) presents them as defence of Christianity as a system belief; vindication of the Christian worldview against its assailants such as atheists, agnostics etc., and refutation of opposing systems and theories such as atheism, pantheism, deism etc. Reymond (1976: 5-7), however, presents four functions of apologetics. The first three are essentially the same as Beattie's (1903). According to Reymond (1976), apologetics addresses objections to the Christian position; it provides an account of the foundations of the Christian faith by examining the theology and epistemology of Christianity; thirdly, it challenges non-Christian systems, particularly in the area of epistemological justification; and finally, it seeks to persuade people of the truth of the Christian position.

\section{Theoretical Foundation}

This paper draws theoretical insights from the Generic Structure Potential model (henceforth, GSP) proposed by Michael Halliday and Ruquiya Hasan (cf. Halliday/Hasan 1985 and Hasan 1996). The model is built on the assumption that Contextual Configuration (CC) - a specific set of the values that realises the field, tenor and mode, "permits statements about the texts structures" to be made (Halliday/Hasan 1985: 56). In other words, Contextual Configuration plays a pivotal role in the structural unity of texts and reveals the relationship between a text and its context. Specifically, a Contextual Configuration can predict the following about text structure:

1. Obligatory elements - What elements must occur?

2. Optional elements - What elements may occur?

3. Sequencing of elements - What arrangements of elements are obligatory and optional?

4. Iteration - How often may what elements occur?

Given a particular Contextual Configuration (CC), Halliday and Hasan (1985) state that it is possible to express the total range of optional and obligatory elements and their order in such a way that we exhaust the possibility of text structure for every text that can be appropriate to a particular CC. This possibility is what is known as the structural potential of this genre or its generic structural potential (GSP). In other words, GSP captures the possible characteristics of texts belonging to a particular genre. It represents the preferred textual organisation for texts in a genre, a preference hinged on the social/communicative purpose the genre sets out to achieve. It is a powerful device that permits a large number of possible structures that can be actualised. Halliday and Hasan (1985) submit that a particular GSP, for instance of Christian apologetics, is known essentially and adequately realised by the set of obligatory elements.

Halliday and Hasan (1985) examine and identify the obligatory and optional rhetorical elements of shop interaction or service encounter. The catalogue is represented below:

\section{(1) \\ $\left[(\mathrm{G}) .(\mathrm{SI})^{\wedge}\right]\left[(\mathrm{SE}.)\left\{\mathrm{SR}^{\wedge} \mathrm{SC}^{\wedge}\right\}^{\wedge} \mathrm{S}^{\wedge}\right] \mathrm{P}^{\wedge} \mathrm{PC}(\mathrm{F})$}

The catalogue above can be read thus: any shop transaction in English should contain the following elements: Greeting (G), Sale initiation (SI), Sale Enquiry (SE), Sale Request (SR), Sale Compliance (SC), Sale (S), Purchase (P), Purchase Closure (PC), and Finis (F). The round brackets in the above GSP indicate optionality of enclosed elements. Therefore G, SI, 
SE, and F are optional and SR SC, S, P, and PC are obligatory. The dot between elements means "more than one option" in sequence. The arrow shows iteration. The braces with a curved arrow indicate that the degree of interaction for elements in the square brackets is equal. That is to say, if SR occurs twice, then SC must also occur twice. Finally, the caret sign $(\wedge)$ shows sequence (Ansary/Babaii 2004: 7).

The GSP approach has been applied to a number of discourses with a view to establishing their genre status, such studies include: discourses on shop interaction (Mitchell 1975); business letters (Ghadessy 1993); introduction sections of research articles (Paltridge 1993); nursery stories (Hasan 1996); introduction and conclusion of essays (Henry and Roseberry 1997); newspaper editorials (Ansary/Babaii 2004); magazine editorials (Odebunmi 2007a). The foregoing shows that the model has not been applied to religious discourse in general and to Christian apologetics in particular. Thus, this paper investigates the GSP of Christian apologetics.

\section{$4 \quad$ Method of Analysis}

Twenty texts from key, contemporary Christian apologetic writers - Robert J Morgan, Ravi Zacharias, William Lane Craig, Thompson Bert, Josh McDowell, Norman L. Geisler, Ryan Turner, Ben Rast, D. Massimo Lorenzini, John Piper - were purposively selected to constitute the data for the study. The underlying motivation for the selection lies in the fact that these apologists address important topics in Christian apologetics such as: the uniqueness of the person of Christ; the reliability of the Bible; the question of creation; evolution; and the Christian response to contemporary philosophical and religious worldviews. To determine the GSP, ten out of the twenty texts were closely examined as sections of the texts that realised the GSP elements were marked and further verified with the remaining ten texts. A GSP catalogue was then generated and representative extracts from the texts were selected to illustrate each element in the catalogue. The findings of the study will be seen presently. The titles of the texts used for analysis are presented below:

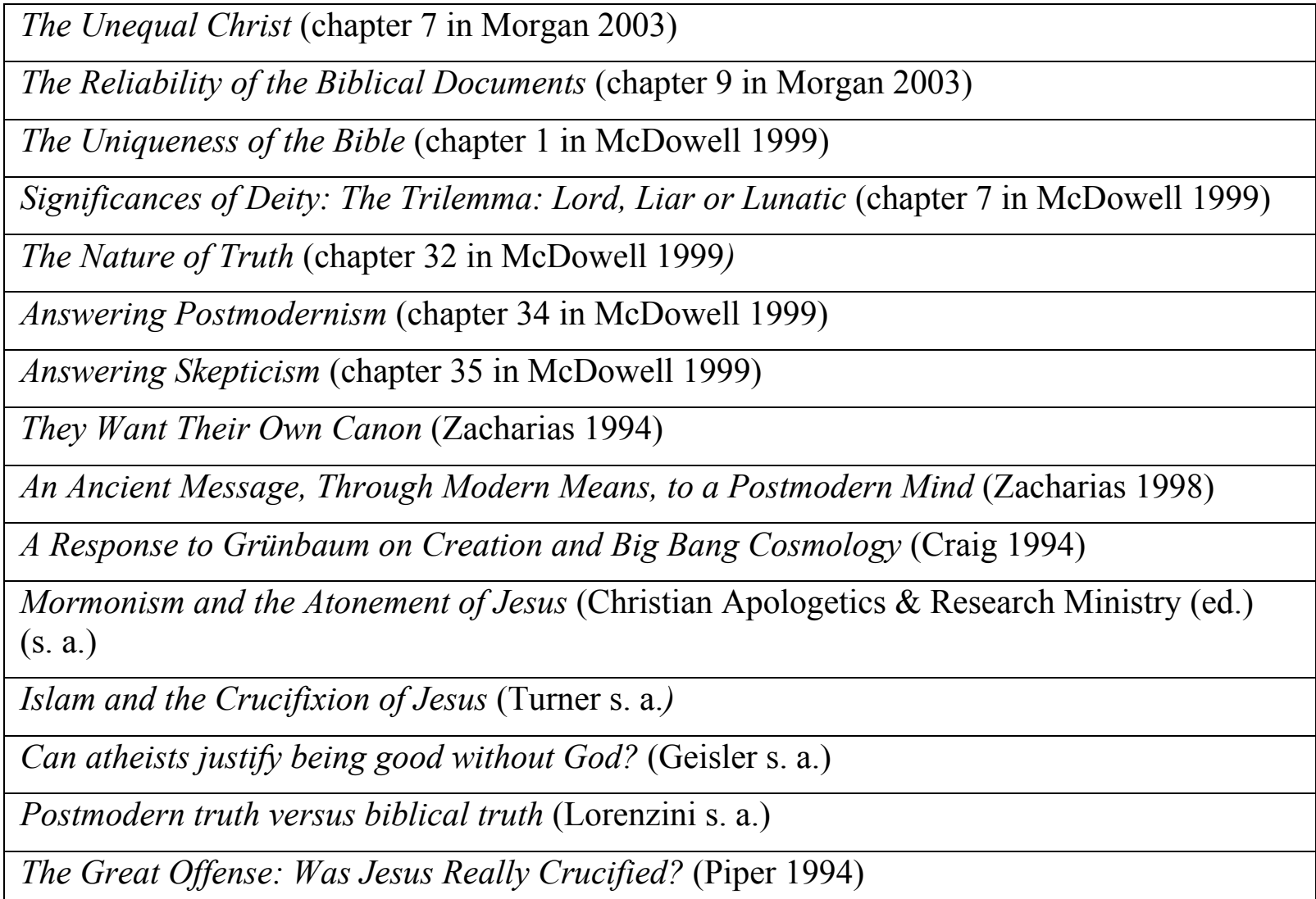


A Comprehensive Biblical Defense of the Trinity (Rast 2004)

The scientific case for creation (Thompson 1999b)

Creation and Big Bang Cosmology (Craig s. a.)

Introduction (Thompson 1999a)

The Many Faces of Unbelief (chapter 2 in Thompson 1999a)

\section{The GSP Catalogue and Explanation}

The following is the GSP catalogue for Christian apologetics:

\begin{tabular}{|c|c|c|}
\hline \multicolumn{3}{|r|}{ The key to the symbols } \\
\hline TT & $=$ & Title \\
\hline AN & $=$ & Author's Name \\
\hline $\mathrm{BI}$ & $=$ & Background Information \\
\hline PCP & $=$ & Presentation of Contrary Positions \\
\hline $\mathrm{AOP}$ & $=$ & Articulating Own Positions \\
\hline $\mathrm{A}$ & $=$ & Argumentation \\
\hline EL & $=$ & Elaboration \\
\hline TMs & $=$ & Testimonials \\
\hline $\mathrm{F}$ & & Finis \\
\hline
\end{tabular}

The elements that constitute the GSP include: Title TT, Author's Name AN, Background Information BI, Presentation of Contrary Positions PCP, Articulating Own Position AOP, Argumentation A, Elaboration EL, Finis F and Testimonials TMs. The round brackets in the catalogue above indicate optionality, therefore, (TM) is the only optional element discovered in the data and TT, AN, BI, PCP, AOP, A, EL, F are obligatory. PCP, AOP, A, EL are recursive and therefore, have the curved arrow ( $A$ ) on them. The dot (.) between elements means that more than one option in sequence is possible. Therefore, the sequence PCP. AOP. A. EL. is only one option, as the sequence could be: AOP. PCP. EL. A. The square brackets [] limit the place of occurrence of the elements within them, which implies, for instance, that $\left[\mathrm{TT}^{\wedge} \mathrm{AN}\right]$ can only occur in the beginning of a Christian apologetic text and nowhere else. The same explanation holds for $[\mathrm{B}]$ and $[\mathrm{F}]$. Finally, the caret sign $\left({ }^{\wedge}\right)$ stands

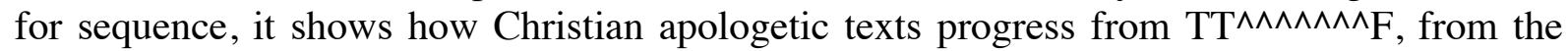
title to the conclusion. The following is a detailed description of each element with excerpts from the texts to illustrate.

Title (TT): this element refers to the title of the text which usually reflects its theme. In the data, some titles are phrases while others are sentences.

Ex. 1: The Unequal Christ (Morgan 2003)

The title in example 1 is a noun phrase and it clearly indicates the writer's position concerning the person of Christ. The title declares that Christ is unequal. Such bold statement of the writers' position from the onset, from the title, is typical of Christian apologetics. As an 
argumentative discourse, it is required that the writers declare their stance even in the title before proceeding to delineate supporting arguments. The next example is a sentence form TT:

\section{Ex. 2: They Want Their Own Canon}

In this title the writer somewhat distances himself from his opponents' desire for "their own canon" and thus undermines their proposition. This strategic dissociation and subtle disqualification, even in the title, is typical of Christian apologetics.

2. Author's Name (AN): this element furnishes readers with the name of the writer of the text. In the data, it is observed that the names of some of the writers are preceded by titles. In the case of books the names of the authors usually appear on the front page. All the writers have $P h . D$. in their various fields. An example of AN is given below:

\section{Ex. 3 Dr. William Lane Craig}

3. Background Information (BI): this element creates the setting for the text as it states the writers' intentions which might include the arguments they intend to debunk, the opponents they plan to engage etc. Thus, BI includes references to people, places, and viewpoints; also it can be a narrative. The following are extracts to substantiate the claims made:

Ex. 4: The French mathematician and philosopher Auguste Comte was talking about religion one day with the Scottish essayist Thomas Carlyle. Comte suggested they start a new religion to replace Christianity, based on positive thinking and mathematical principles. Carlyle thought a moment and replied, "Very good, Mr. Comte, very good. All you will need to do will be to speak as never a man spake, and live as never a man lived, and be crucified, and rise again the third day, and get the world to believe that you are still alive. Then your religion will have a chance to get on." (Morgan 2003: 61)

This BI narrates Auguste Comte's proposal to start a new religion that would replace Christianity, and the response of Thomas Carlyle to the proposal. The narrative provides the background for the discussion that follows later in the text on the uniqueness of Christ, as such BI prepares readers for what to expect in the text. For instance, since Comte cannot possibly meet the criteria suggested by Carlyle, his chances of starting a new religion that would substitute Christian is slim; so that even from the BI the writer's position that the founder of Christianity is unequal is made clear, albeit, subtly. The next example further illustrates BI:

Ex. 5: VISITING THE ROTUNDA of the National Archives in Washington is an almost sacred experience. The hallowed room, round and regal and as solemn as a cathedral, is designed to preserve one of the greatest documents in human history - the American Declaration of Independence. This venerable document rests under green-filtered glass in a bronze case filled with inert helium gas and is lowered every night into a climate-controlled vault some twentytwo feet below the floor. (Morgan 2003: 78)

In this example, the writer recounts the sacred experience of visiting the "Rotunda of the National Archives in Washington", which houses the American Declaration of Independence, a document described as the greatest in human history. Here again, the BI sets the stage for the readers as the text discusses the reliability of the Biblical documents. The implication, which the writer makes clear later in the text, is that if the Americans consider the Declaration of Independence a reliable and vital document, so do the Christians, the Bible. A careful reading of the BI indicates that it reveals the intention of the writer: to argue for the reliability of the biblical documents. One more example of BI can be considered:

Ex. 6: Recently I had the privilege of being on a live, albeit brief, interview over CNN on Christmas Eve. I prepared myself by having carefully reviewed the current spate of articles in Time, U.S. News and World Report, and the like, as well as the many recent books disclosing 
the "latest findings" of some liberal critics who are ever keen to remake Jesus in their own image. Interestingly enough, although my host did not mention any one of them by name, his questions betrayed the popular mood engendered by these so-called biblical scholars who seem to delight in making a living by debunking the Bible. (Zacharias 1994: 1)

Example 6 is bifocal, i.e., it presents on the one hand the writer's personal experience as he prepares for an interview over $\mathrm{CNN}$, and it lays out the contrary positions he intends to engage in the text. In recounting his experience, the writer indicates that he "carefully reviewed the current spate of articles in Time, U.S. News and World Report, and the like, as well as the many recent books disclosing the 'latest findings'...". Such a claim has the potential of suggesting that the writer is widely read, more acquainted with the views of the opponents and better equipped to discredit them. The writer's self-exposition creates a positive aura which has a way of attracting intelligent readers to him. In addition, this reveals that BI does not only provide the backdrop for the text and the intention of the writer, but could also present the credentials of the writer.

From the foregoing, it can be surmised that BI is a very important element in the GSP of Christian apologetics because it provides a backdrop for the texts in this discourse; reveals the intentions of the writers, and occasionally gives off the writers' credentials. It is also an obligatory element.

4. Presentation of Contrary Positions (PCPs): this element captures the segment of the texts that presents positions contrary to those of Christian apologetic writers. These contrary positions are what the apologetic writers attempt to disclaim. In some of the texts only a single central PCP is stated, while in others multiple PCPs are broached. The identification of the segments that realise the PCP element is greatly influenced by certain linguistic items italicised in the examples below:

Ex. 7: Early in the nineteenth century, it became fashionable in some circles to discount the uniqueness of Christ by questioning His very existence in history. In Germany some of the higher critics openly doubted the historicity of Christ, suggesting that the stories about Him were a myth like those of the Greek and Roman gods, or perhaps shadowy legends like those of King Arthur and Camelot. (Morgan 2003: 61)

The text, from which this example is drawn, is concerned with the uniqueness of Christ and it takes as its point of departure the fact that Christ existed as a historical person. Naturally, a contrary view is the claim that Christ did not exist as a historical figure, and in this text, the writer cites a contrary position that holds this view. The writer says that it was "fashionable in some circles to discount the uniqueness of Christ by questioning His very existence in history..." He then specifically mentions the German higher critics who openly doubted the very existence of Christ suggesting that Christ could as well have been a myth or one of the "shadowy legends". This position is indicated for the sole purpose of being engaged and debunked by the apologetic writer, as the remainder of the text presents arguments that disclaim the view expressed in the Text's PCP. It can be argued that without this segment in this text, its purpose will be drastically altered, for Christian apologetics thrives on discrediting worldviews that are contrary to the Christian belief system. The next example presents a PCP expressed by Barbara Thiering, an Australian writer.

Ex. 8: Australian writer Barbara Thiering suggests that Jesus married Mary, had three children, and then divorced her and married Lydia. (Zacharias 1994)

Barbara Thiering suggests that "Jesus married Mary, had three children, and then divorced her and married Lydia". This proposition negates the beliefs of Christianity and what it teaches about Christ. Its reference is in keeping with the requirement of Christian apologetics: to reference and disclaim any other position that is false and to uphold the Christian position. 
From the discussion above, we have shown that PCP is an important and obligatory element in the GSP of Christian apologetics. The element allows Christian apologetic writers to present positions that run contrary to their own and to show how they are not consistent with the values espoused in Christianity. The presence of this element provides one of the justifications for the existence of Christian apologetics. In other words, if there are no contrary positions to counteract, there will be no need for apologetics; there will be no need to defend the Christian position. As a matter of fact, the overarching metaphor suitable for the description of Christian apologetics is that of a battle. Every contrary position is seen as a threat that needs to be neutralised at all cost by Christian apologists.

5. Articulating Own Position (AOP): in this segment of the texts, the writers articulate their own positions on the issues being debated and they also cite authors that share their positions. It should be quickly noted that their position on any issue is not merely the writer's/author's opinion on the issue but a re-echo of their Christian or institutional worldviews. Certain linguistic items in the texts also help to identify the segments of the text that realise this element and they are italicised in the examples below.

Ex. 9: In surveying the evidence for the reliability of Christianity, we have looked at the empty tomb, the complexity of creation, and the fulfillment of prophecy. Now we come to the person of Christ Himself, about whom A. I. Pierson said, "He stands absolutely alone in history; in teaching, in example, in character, an exception, a marvel, and He is Himself the evidence of Christianity. He authenticates Himself."

Christ alone, in His history and in His character, serves as a material witness in His own behalf. Anyone who wants to discredit Christianity must somehow explain away the uniqueness of Jesus of Nazareth.

Ex. 10: Simply put, Jesus is absolutely unequaled in history.

Ex. 11: No other figure in history has ever made such claims, and no one else has ever risen from the dead by his own power. None but Christ. (Morgan 2003: 61f., 66)

Examples 9-11 express the writer's position on Christ. In Ex. 9, the writer previews other arguments for the reliability of Christianity, before focusing on the person of Christ. He quotes an author, A. I. Pierson, who in describing Christ says that "He stands absolutely alone in history; .... He is Himself the evidence of Christianity....". The writer further endorses this position by restating A.I Pierson's position and concluding that "Anyone who wants to discredit Christianity must somehow explain away the uniqueness of Jesus of Nazareth." The prior is a clear statement on the Christian belief concerning the person of Christ. Thus, the AOP element of GSP of Christian apologetics enables Christian apologetic writers to articulate their positions, which, of course, is targeted at countering those advanced by nonChristian worldviews. Ex. 10 and 11 also convey the writer's position in a more poignant fashion. In one of these examples, the writer makes a very absolute statement that undermines any contrary position: "Simply put, Jesus is absolutely unequaled in history". The word absolutely reveals how very strongly this writer articulates his position. Other examples of AOP are presented below:

Ex. 12: Christians also have a founding document on which our spiritual faith and freedom are based, one more fabulous than even the Declaration of Independence. It is the Bible, composed over 1,600 years in sixty-six installments, written in three languages on three continents. It has a central theme and a unifying scheme; and Christians, believing it inspired by God, consider it infallible, inerrant, and sufficient for all human need.

Ex. 13: In summary, we have documents reaching to within a generation of the original writers, and the details that emerge from the New Testament's pages show these documents to be 
historically reliable and well-researched. They were accurate in their composition. (Morgan 2003:79, 83f.)

In articulating his position in Ex. 12, the writer compares the Bible with the American Declaration of Independence, and states that the Bible is even "more fabulous". He then highlights some features of the Bible, which compel him to adopt such a stance concerning it. In Ex. 13, the writer zeros in on the accuracy of the Bible. The relevance of this AOP will be more poignant when it is placed side by side some of the PCPs discussed above, especially the one that doubted the historical reliability of the Bible. The objective of the AOP is to neutralise the views represented by the PCPs segment of the discourse. Thus, it is an important element of Christian apologetics as it serves as the adjacency pair of PCP.

Ex. 14: On the theistic hypothesis, the potentiality of the universe's existence lay in the power of God to create it.

Ex. 15: Therefore, the cause of the universe is plausibly regarded as personal. This conclusion receives confirmation from the incredible complexity of the initial conditions given in the early universe, which bespeak intelligent design [Leslie (1990)]. These attributes are some of the core properties of what theists mean by "God." (Craig 1994)

Ex. 14 and 15 articulate the writer's position on the question of the existence of the universe. The writer, being a theist, claims that the potentiality of the universe's existence lay in the power of God to create it. He further argues that the complexity of the universe confirms his conclusion. The writer uses cosmological, scientific facts to base his position.

As was noted earlier, AOP is the adjacency pair of PCP in the GSP of Christian apologetics. While PCP advances the position contrary to the apologists', AOP articulates the apologist's own position in response to the PCP. It is an important and obligatory element in view of the fact that it balances the discourse as its sole aim is to first respond to contrary positions, and then to enunciate the apologists' point of view on the subject of debate.

6. Argumentation (A): this element refers to the process of argumentation and the arguments produced. Argumentation has to do with the use of language to justify or refute a viewpoint, with the purpose of securing agreement in views. In Christian apologetics, this element plays a pivotal role, as it helps to set the positions and counter-positions. It also helps to achieve the objective of Christian apologetic discourse, which is to argue for truth as espoused by Christians. The following are illustrations of this element from the data:

The objective of text titled The Unequal Christ is to bring the reader to accept the writer's point that Christ is unique and unequal. Thus, the arguments cited and analysed below are targeted at achieving this objective.

\section{Ex. 16: Argument: The extraordinary feats of Jesus}

Philip Schaff put it very well when he wrote: This Jesus of Nazareth, without money and arms, conquered more millions than Alexander, Caesar, Mohammed, and Napoleon; without science and learning, He shed more light on matters human and divine than all the philosophers and scholars combined; without the eloquence of schools, He spoke such words of life as were never spoken before or since and produced effects which lie beyond the reach of orator or poet; without writing a single line, he set more pens in motion, and furnished themes for more sermons, orations, discussion, learned volumes, works of art, and songs of praise than the whole army of great men of ancient and modern times. (Morgan 2003)

This source quoted by the writer of this text argues for the uniqueness of Christ by listing out the achievements of Christ. He compares the conquest of Christ to those of "Alexander, Caesar, Mohammed, and Napoleon" and states that Christ conquered more. He compares the illumination Christ gave to matters both human and divine to those given by "all the philosophers and scholars combined" and claims that Christ's was more enlightening. He compares the effects of Christ's words on people to those of orators and poets and submits 
that Christ's lay beyond theirs. He compares the contemplations of various people on Christ to those elicited by "the whole army of great men of ancient and modern times" and affirms that Christ's is more. The writer further indicates that Christ was disadvantaged when compared with these other great people. For instance, the writer avers that Christ was "without science and learning"; "without the eloquence of schools"; and "without writing a single line" yet He greatly surpassed the people that had these privileges. The next example presents the argument that Luke's gospel is historically accurate.

Ex. 17: Argument: Luke's Gospel is historically accurate.

Luke tacks John's ministry to the wall of history using six different pins. John the Baptist appeared when (1) Tiberius Caesar was in his fifteenth year of rule; (2) Pontius Pilate was governor of Judea (3) Herod was tetrarch of Galilee; (4) Herod's brother Philip was tetrarch of Iturea and Traconitis; (5) Lysanias was tetrarch of Abilene; and (6) Annas and Caiaphas were sharing the office of high priest. Most of these facts are easy to verify, but a couple of them caused problems. (Morgan 2003)

In this example of Argumentation, the writer argues for the reliability of the Gospel according to Luke by claiming that it is historically accurate. The writer asserts that the historical context in which Luke steeps the ministry of John the Baptist is verifiable and has been confirmed to be accurate. This historical accuracy makes the Gospel and by extension the entire Bible reliable and trustworthy.

Ex. 18: Argument: There are 5,000 Greek manuscripts of the New Testament dating to within about 25 years of its actual writings

However, we have not ten or eleven manuscripts, but five thousand Greek manuscripts of the New Testament, dating to within twenty-five years or so of the actual writings. We have translations, quotations, and readings going back to the earliest times of the Christian church. "From the standpoint of literary evidence," writes Professor Berkeley Mickelsen, "the only logical conclusion is that the case for the reliability of the New Testament is infinitely stronger than that for any other record of antiquity." (Morgan 2003)

This example of Argumentation still furthers the apologist's position on the reliability of Biblical documents. The writer avers that there are 5,000 Greek manuscripts of the New Testament dating to within 25 years of its actual writings, and that there are translations, quotations "going back to the earliest times of the Christian church". This is in comparison to other classic texts with not more than 10 or 11 extant copies dating to some thousand years to their original copies. The writer corroborates his argument by quoting a source who asserts that judging from a literary perspective "the only logical conclusion is that the case for the reliability of the New Testament is infinitely stronger than that for any other record of antiquity". The writer drives his argument home by first, citing the number of manuscripts of the New Testament, and second, by quoting the opinion of a professor regarding the reliability of the Bible.

In the analysis under Argumentation, we have shown how this element features very prominently in Christian apologetics. Christian apologetics is an argumentative discourse whose social or communicative purpose is to argue for the reliability and validity of the Christian worldview and to get its readers to agree and this makes the element an obligatory one.

Before we proceed to other elements, there is the need to distinguish between AOP, which of course is the pair of PCP, and A. AOP is, more or less, the thesis statement of apologetic texts and provides the basis for subsequent Argumentations/arguments in favour of the apologists' articulated position. Apologetic writers present their position on the subject of debate in their AOP, which is a form of argumentation; albeit an overriding one and they give supporting arguments in the Argumentation element of their writings. Put simply, AOP is the apologetic 
writers' macro-argument for which other instances of Argumentations are micro. The same understanding of macro/micro division is applicable to PCP and Argumentation in its favour.

7. Elaboration (EL): this element provides more detailed description or exemplification of the arguments presented, or acts to restate them, or describes the material in the arguments in different terms. The following examples of EL are presented below:

\section{Ex. 19: An illustration on the power of magnetism}

I recently heard a reporter describe her impression of Reagan as he arrived in Washington, having just been elected president of the United States. She admitted she disliked Reagan's policies and philosophy, but she said that when she saw him emerge from the airplane, tall and handsome and self-assured, dressed in a dark overcoat with a white scarf around his neck, when she saw his thick, dark hair catching the snowflakes, and when she watched him bounce confidently down the steps, she was mesmerized. "There was an irresistible power to his presence," she said. "It drew you in. It was like an electric force." (Morgan 2003)

This EL is an illustration on the power of magnetism. It describes the impression a particular reporter had of Reagan, a former American president. The reporter admitted that she disliked the policies and philosophy of Reagan, but the moment she saw him, all her reservations vanished. She said that there was an irresistible power to his presence. In the text, the writer had earlier argued on the magnetic life of Christ, and by this illustration restates his argument more poignantly. The writer uses the magnetic life of a readily accessible personality to illustrate and restate his argument concerning the magnetism of Christ who lived over two thousand years ago.

The element Elaboration plays the important role of recontextualising the arguments of the writers of Christian apologetic texts. It enables the apologetic writers to provide more detailed, readily accessible illustrations for their arguments.

8. Testimonials (TM): this structural element refers to certain parts of Christian apologetic texts that narrate the powerful change that comes to people's lives as a result of embracing the truth of the Christian faith. It is an optional element and is a form of argument that seems to mean: besides being philosophically and logically consistent, Christianity has the amazing capacity to change people for good. Two extracts from the data will suffice to illustrate this element:

Ex. 20: Lew Wallace was a famous general and literary genius of the nineteenth century who, along with his friend Robert Ingersoll, decided to write a book that would forever destroy "the myth of Christianity." For two years, Wallace studied in the libraries of Europe and America. Then he started his book. But while writing the second chapter, he found himself on his knees crying out to Jesus Christ in the words of Thomas, "My Lord and my God." The book he was writing became the great novel about the times of Christ, Ben Hur.

Ex. 21: Bill Murray was a businessman who grew up in a home that had rejected God so completely that his mother once told him, "I don't care if you become a drug addict or a bank robber or if you bring home a boyfriend instead of a girlfriend. There's just one thing I don't want you to do in life - become a Christian."

So Bill grew up sexually promiscuous, moving from one marriage to another, from one sexual partner to another. He began drinking and drugging; wanting more and more possessions, he worked himself to exhaustion. He collapsed inwardly and found himself praying to the God he had rejected, "Please, get me out of this mess!" Going to an all night bookstore, he found a Bible buried under a stack of pornographic magazines, and he began reading about Jesus Christ. He was especially drawn to Luke's Gospel, and, as he read it, he grew convinced that Jesus was unique in history, unequaled in His magnetism, His teachings, His claims, His resurrection, and His impact on history.

Bill received Christ as his Savior, and it changed his life. He gave up his drinking, drugging, promiscuous sex, and rampant materialism. He found the inner peace and joy he had always 
been looking for. Bill Murray, ironically, is the son of atheist Madalyn Murray O'Hare, who used him as the plaintiff in the Supreme Court case that outlawed prayer from the public classrooms of America. (Morgan 2003: 66f.)

The TMs above narrate the stories of two men and the transforming result of their believing in Christ. The first man is Lew Wallace, a famous general and literary genius. He collaborates with his friend, Robert Ingersoll, to write a book that will destroy "the myth of Christianity." After two years of research, and while writing the second chapter, he was convinced that Christianity was not a myth. Consequently, he believed in Christ. The second man is Bill Murray, a businessman who had a very strong atheist background, a sexually promiscuous life, an addiction to alcohol and drugs as well as an insatiable desire for material wealth. He got frustrated with his life and surrendered to Christ. This singular act changed his life. In Christian apologetics, the motivation for TM, like the ones above, is to demonstrate the power of the Christian faith to transform people's lives for good.

9. Finis (F): this element signifies that the text has come to a close. It restates the intention and position of the apologetic writer.

Ex. 22: There are only three logical options when it comes to Jesus. Either He was a liar, a hoax,
a deceiver, an impostor - in which case you have to explain how He could also have been the
greatest spiritual leader and the most selfless atoning sacrifice the world has ever known; or He
was a lunatic - in which case you have to explain how He could have been the wisest teacher
the world has ever seen; or He is the God - man which is just who He claimed to be.

Liar, lunatic, or Lord. The answer, it seems, is obvious. (Morgan 2003: 67)

This Finis concludes the discussion on the unequal Christ. It restates the three options about the person of Christ: a liar, lunatic or Lord and the various implications of these options. The writer then asserts that the answer concerning the person of Christ is obvious. In the extract above, the writer packs his argument in one last attempt to drive home his point. Another example of Finis is given below:

Ex 23: When you hold the Gospels in your hand, you are holding documents that give us reliable accounts, well researched by biographers and writers including the most eminent historian of the ancient world, of a man from Nazareth who lived for thirty years as a village carpenter. He preached for the next three years, making claims for Himself that no other had ever made, and driving home His claims with so much evidence that He overturned the Jewish theology of His audience and convinced them that He was, in fact, the Messiah of Israel and the Master of the world. He healed the blind, raised the dead, and filled the hopeless with joy. He allowed Himself to be executed in a most excruciating manner, and then His grave was found vacated. He showed Himself alive by many convincing proofs and so changed the world that today, after two thousand years of human history, His message is more widely believed than ever before. These things were investigated thoroughly from the beginning and written in an orderly account that we might have a solid basis for faith, that we may know the certainty of the things we have been taught. (Morgan 2003: 86f.)

Ex. 23 addresses the reader directly as "you" and asserts that as readers hold the Bible in their hands, they are holding "reliable accounts, well researched by biographers and writers including the most eminent historian of the ancient world, of a man from Nazareth who lived for thirty years as a village carpenter". The writer simply reaffirms his point that the Bible is a reliable document and thus rests his case.

From the foregoing, it can be seen that Finis is the element in the GSP of Christian apologetics that signals the conclusion of the discussion in a particular text. The writers restate their positions and make assertions concerning key issues in Christianity. It also signals the closure of the discourse. 


\section{Conclusion}

The paper examines the GSP of Christian apologetics, and argues that the elements of the GSP model work together to achieve the social/communicative purpose of the discourse, which is to argue for or defend Christian beliefs. In the literature, genre categorization is determined by the communicative purpose of the discourse, since Christian apologetics argues for the truth, validity and reliability of the Christian belief system, it belongs to the arguing genre. For instance, the preferred textual organisation of any text belonging to Christian apologetics has to have elements like PCP and AOP, which serve as adjacency pair. They are so described because PCP presents contrary views to which Christian apologetic writers respond in the AOP of their writings. Finally, the model generated proves to have high educational and pedagogical value, as it can enable apprentice in this discourse community to effectively model their writings. Future research could apply this model to other forms of apologetic discourses such as Islamic apologetics, Catholic apologetics etc. to further test its validity.

\section{References}

Ansary, Hasan/Babaii, Esmat (2004): "The Generic Integrity of Newspaper Editorials: A Systemic Functional Perspective". Asian EFL Journal 6: 1-28.

Babatunde, Sola Timothy (2007): "A Speech Act Analysis of Christian Religious Speeches". In Odebunmi, Akin/Babajide, Adeyemi O. (eds.) (2007): Style in Religious Communication in Nigeria. München: Lincom Europa: 48-89.

Batts, Martin (1977): A Summary and Critique of the Historical Apologetic of John Warwick Montgomery. Th. M. thesis, Dallas Theological Seminary.

Beattie, Francis R. (1903): Apologetics or The Rational Vindication of Christianity. 3 vols. Richmond: Presbyterian Committee of Publications.

Boa, Ken D./Bowman, Robert M. (2005): Faith Has Its Reasons: An Integrative Approach to Defending Christianity. Colorado Springs: Navpress.

Christian Apologetics \& Research Ministry (ed.) (s.a.). Mormonism and the atonement of Jesus. Available at http://carm.org/mormonism-and-atonement-of-jesus, accessed June 27, 2011.

Craig, William Lane (1994): "A Response to Grünbaum on Creation and Big Bang Cosmology." Philosophia Naturalis 31: 237-249.

Craig, William Lane (s.a.): Creation and Big Bang Cosmology. Available at http://www.leaderu.com/offices/billcraig/docs/creation.html, accessed September 19, 2012.

Crystal, David (1965): Linguistics, language and religion. London: Burns Oates.

Crystal, David and Davy, Derek (1969): Investigating English style. England: Longman Group Limited.

Geisler, Norman L. (s. a.): Can atheists justify being good without God? Available at http://www.normgeisler.com/articles/Atheism/CanAtheistsBeingGoodWithoutGod.htm, accessed June 27, 2011.

Ghadessy, Mohsen (1993): "On the nature of written business communication." In id. (ed.) (1993): Register analysis: theory and practice. London: Printer Publisher: 149-164.

Halliday, Michael A. K./Hasan, Ruqaiya (1985): Language, Context and Text: Aspects of Language in a Social Semiotic Perspective. Oxford: Oxford University Press.

Hasan, Ruqaiya (1996): Ways of Saying: Ways of Meaning. London \& New York: Cassell.

Henry, Alex/Roseberry, Robert L. (1997): "An investigation of the functions, strategies and linguistic features of the introductions and conclusions of essays". System 25 (4): 479-495.

Lorenzini, D. M. (s.a.): "Postmodern truth versus biblical truth". Available at http://www.frontlinemin.org/truth.asp, accessed June 27, 2011. 
McDowell, Josh (1999): The new evidence that demands a verdict. Nashville: Thomas Nelson publishers.

Mitchell, Terence (1975): "The language of buying and selling in Cyrenaica: a situational segment". In id. (ed.) (1975): The principles of Firthian linguistics. London: Longman: 167-200.

Morgan, Robert J. (2003): Evidence and Truth: Foundations for Christian Truth. Illinois: Crossway Books.

Odebunmi, Akin (2007a): "Explicatures and Implicatures in News Magazine Editorials: The Case of the Nigerian Tell". In Taiwo, Rotimi et al. (eds.) (2007): Perspectives on Media Discourse. Lincom Europa: 84-98.

Odebunmi, Akin (2007b): "The Stylistics of Religious Electronic Media Advertisement in Nigeria". In Odebunmi, Akin/Babajide, Adeyemi O. (eds.) (2007): Style in Religious Communication in Nigeria. München: Lincom Europa: 1-26.

Paltridge, Brian (1993): "Writing up research: a systemic functional perspective". System 21 (2): $175-192$.

Piper, John (1994): The Great Offense: Was Jesus Really Crucified? Available at http://www.desiringgod.org/resource-library/articles/the-great-offense-was-jesus-reallycrucified, accessed June 27, 2011.

Ramm, Bernard (1972): A Christian appeal to reason. Waco, Texas: Word.

Rast, Ben (2004): A Comprehensive Biblical Defense of the Trinity. Available at http://www.contenderministries.org/biblestudy/trinity.php, accessed June 27, 2011.

Reymond, Robert L. (1976): The Justification of Knowledge: An Introductory Study in Christian Apologetic Methodology. Phillipsburg, N. J.: Presbyterian \& Reformed.

Samarin, William (1976): "The Language of Religion". In id. (ed.) (1976): Language in Religious Practice. Rowley: 3-14.

Taiwo, Rotimi (2007): "Tenor in Electronic Media Christian Discourse in Nigeria". Nordic Journal of African Studies 16 (1): 75-89.

Thompson, Bert (1999a): The Many Faces and Causes of Unbelief. Alabama: Apologetic Press. Available at http://www.apologeticspress.org/pdfs/courses_pdf/hsc0101.pdf, accessed September 22, 2010.

Thompson, Bert (1999b): The Scientific Case for Creation. Alabama: Apologetic Press. Available at http://www.apologeticspress.org/pdfs/e-books_pdf/scfc.pdf, accessed September 22, 2010.

Turner, Ryan (s. a.): Islam and the Crucifixion of Jesus. Available at http://carm.org/islamcrucifixion-of-jesus, accessed June 27, 2011.

Zacharias, Ravi (1994): They want their own canon. Available at http://www.rzim.org/justthinking/they-want-their-own-canon/, accessed September 22, 2010.

Zacharias, Ravi (1998): An Ancient Message, Through Modern Means, to a Postmodern Mind. Available at http://www.rzim.org/just-thinking/an-ancient-message-throughmodern-means-to-a-postmodern-mind/, accessed September 22, 2010. 